\title{
The sweet potato sporamin promoter confers high-level phytase expression and improves organic phosphorus acquisition and tuber yield of transgenic potato
}

\author{
Ya-Fang Hong · Chang-Yeu Liu · Kuo-Joan Cheng • \\ Ai-Ling Hour · Min-Tsair Chan · Tung-Hai Tseng • \\ Kai-Yi Chen · Jei-Fu Shaw $\cdot$ Su-May Yu
}

Received: 9 December 2007/ Accepted: 18 March 2008/Published online: 4 April 2008

(C) Springer Science+Business Media B.V. 2008

\begin{abstract}
The sweet potato sporamin promoter was used to control the expression in transgenic potato of the E. coli appA gene, which encodes a bifunctional enzyme exhibiting both acid phosphatase and phytase activities. The sporamin promoter was highly active in leaves, stems and different size tubers of transgenic potato, with levels of phytase expression ranging from 3.8 to $7.4 \%$ of total soluble proteins. Phytase expression levels in transgenic potato tubers were stable over several cycles of propagation. Field tests showed that tuber size, number and yield increased in transgenic potato. Improved phosphorus (P) acquisition when phytate was provided as a sole $\mathrm{P}$ source and enhanced microtuber formation in cultured transgenic potato seedlings when phytate was provided as
\end{abstract}

Electronic supplementary material The online version of this article (doi:10.1007/s11103-008-9324-6) contains supplementary material, which is available to authorized users.

Y.-F. Hong

Graduate Institute of Life Sciences, National Defence

University, Neihu, Taipei 114, Taiwan, ROC

Y.-F. Hong · S.-M. Yu ( $\varangle)$

Institute of Molecular Biology, Academia Sinica, Nankang,

Taipei 115, Taiwan, ROC

e-mail: sumay@imb.sinica.edu.tw

C.-Y. Liu

Division of Applied Biology, Animal Technology Institute

Taiwan, Chunan, Miaoli 350, Taiwan, ROC

K.-J. Cheng · M.-T. Chan

Agricultural Biotechnology Research Center, Academia Sinica, Nankang, Taipei 115, Taiwan, ROC an additional $\mathrm{P}$ source were observed, which may account for the increase in leaf chloroplast accumulation (important for photosynthesis) and tuber yield of field-grown transgenic potato supplemented with organic fertilizers. Animal feeding tests indicated that the potato-produced phytase supplement was as effective as a commercially available microbial phytase in increasing the availability of phytate$\mathrm{P}$ to weanling pigs. This study demonstrates that the sporamin promoter can effectively direct high-level recombinant protein expression in potato tubers. Moreover, overexpression of phytase in transgenic potato not only offers an ideal feed additive for improving phytate-P digestibility in monogastric animals but also improves tuber yield, enhances $\mathrm{P}$ acquisition from organic fertilizers, and has a potential for phytoremediation.

Keywords Sporamin promoter - Phytase - Potato · Sweet potato $\cdot$ Feed additive $\cdot$ Tuber yield and size

\author{
A.-L. Hour \\ Department of Life Science, Fu Jen Catholic University, \\ Taipei 242, Taiwan, ROC \\ T.-H. Tseng \\ Division of Biotechnology, Taiwan Agricultural Research \\ Institute, Wu-Fong, Taichung 413, Taiwan, ROC \\ K.-Y. Chen \\ Department of Agronomy, National Taiwan University, \\ Taipei 106, Taiwan, ROC \\ J.-F. Shaw \\ Institute of Plant and Microbial Sciences, Academia Sinica, \\ Nankang, Taipei 115, Taiwan, ROC
}




\section{Introduction}

Potato is the world's fourth most important food crop. Potato tubers are ideal for the production of recombinant proteins (commonly termed as plant molecular farming) for the following reasons: (1) specialized as a storage organ, tubers can accumulate large amounts of proteins; (2) standard processes currently used in the starch industry may be adapted with little modification to separate proteins from tubers; (3) as with most storage organs, tubers feature a low hydrolytic profile, facilitating protein stability; (4) speedy upscaling of tubers of a selected transformant can be easily obtained by in vitro vegetative propagation; (5) accumulated recombinant proteins are fairly stable for up to 6 months, facilitating the processing of large amounts of tubers at a chosen time (Artsaenko et al. 1998; De Wilde 2002); and (6) tubers can be produced rapidly and cost-effectively in the greenhouse under controlled conditions, which could be important for production of pharmaceutical proteins.

Patatin is the most abundant storage protein in potato. The patatin and CaMV35S promoters are commonly used for expression of recombinant proteins in potato tubers, but in most cases with yields far below $1 \%$ of total soluble proteins (TSP) (Chong and Langridge 2000; Richter et al. 2000; Tacket et al. 2000; De Wilde 2002; Farran et al. 2002). In rare cases, with the enhanced CaMV35S promoter, yields up to $2 \%$ of TSP could be reached (Artsaenko et al. 1998; Scheller et al. 2001). Granulebound starch synthase (GBSS) promoter has been shown to be 3 - to 25 -fold more active than the CaMV35S promoter in transgenic potato, but its activity is similar to the patatin promoter (Visser et al. 1991). To maximize the expression level of recombinant proteins, it appears there is a need to identify more promoters that are highly active in potato tubers. Sporamin is the most abundant storage protein in sweet potato. In field-grown sweet potato plants, sporamin is preferentially accumulated in tuberous roots ( $80 \%$ of TSP); however, in cultured sweet potato seedlings provided with sucrose, sporamin is preferentially accumulated in stems (70\% of TSP) (Hattori et al. 1990). The $1-\mathrm{kb}$ promoter of one sporamin gene, SPO-A1, fused with a reporter gene, has also been shown to be preferentially expressed in stems of transgenic tobacco plants cultured on sucrose-containing medium (Hattori et al. 1990; Ohta et al. 1991). These studies suggest that sporamin accumulation and its promoter activity in stems of sweet potato and transgenic tobacco, respectively, are induced by sucrose. Similar regulation has also been observed for patatin accumulation and its promoter activity in potato (Rocha-Sosa et al. 1989; Wenzler et al. 1989). The accumulation of sporamin in sweet potato and patatin in potato tubers was concomitant with the accumulation of starch (Paiva et al. 1983; Rocha-Sosa et al.
1989; Hattori et al. 1990), suggesting that accumulation of these storage proteins in sink tissues could be up-regulated by anabolic signals at the transcriptional level. Consequently, the sporamin promoter was considered for driving recombinant protein expression in the transgenic potato tuber as it is a sink tissue.

Phytate (myo-inositol hexakisphosphate) is the main storage form of $\mathrm{P}$ in soybean and corn meals that constitute major components of animal feeds. However, monogastric animals (e.g., pigs, poultry and fish) utilize phytate extremely poorly due to the absence of gastrointestinal tract enzymes capable of hydrolyzing phytate. When used as feed, phytate $\mathrm{P}$ is not utilized by monogastric animals, excreted in the manure, and becomes a potential source of phosphate pollution through the action of microbial phytase in soil. $\mathrm{P}$ availability to monogastric animals has been improved by the supplementation of animal feed with phytase (myoinositol hexakisphosphate phosphohydrolase, EC 3.1.3.8) from the fungus Aspergillus niger (Maenz 2001). Phytase sequentially dephosphorylates phytate to yield inorganic phosphate and myo-inositol, which are then absorbed in the small intestine. Transgenic plant-produced phytases have been shown to efficiently substitute for the microbial enzyme in poultry-feeding studies (Pen et al. 1993; Denbow et al. 1998). The appA gene of E. coli encodes a bifunctional enzyme exhibiting both acid phosphatase and phytase activities that have identical $\mathrm{pH}$ optima of 4.5, and are active at $\mathrm{pH}$ values from 2.0 to 6.0 (Golovan et al. 2000). Properties of the phytase encoded by appA, including the broad low $\mathrm{pH}$ optima, high specific activity, and protease resistance (Cheng et al. 1999; Golovan et al. 2000), suggest that this enzyme is a good candidate for industrial production as a feed enzyme.

$\mathrm{P}$ is an essential but often limiting nutrient for plant growth and development. Large amount of $\mathrm{P}$ fertilizers are applied to cropland to promote high yield, but only 10-20\% of the fertilizer $\mathrm{P}$ is readily utilized by plants (Holford 1997). Most fertilizer $\mathrm{P}$ becomes fixed forms in soil that are only poorly available to plants (Vance et al. 2003). Thus, the large input of $\mathrm{P}$ fertilizer is not only expensive but also nonsustainable. On the other hand, $\mathrm{P}$ has been recycling among plants, animals and microorganisms in soil, and therefore, organic P could make up $20-80 \%$ of the total P in soil (Dalal 1977). The predominant form of organic $P$ is phytate, which could account for up to half of organic P in soil (Dalal 1977). It is well-documented that ectopic overexpression of secretory phytase in transgenic plants lead to improved acquisition of $\mathrm{P}$ from phytate in culture medium (Richardson et al. 2001; Mudge et al. 2003; Xiao et al. 2005) and soil (Zimmermann et al. 2003; George et al. 2005). Consequently, in addition to exploring the feasibility of using the sporamin promoter to drive the expression of phytase in transgenic potato tubers for use as a feed additive, we also 
like to study whether P uptake efficiency by transgenic potato could be improved by this approach.

In the present study, an 1.1-kb sporamin gene (SPO) promoter was isolated from sweet potato and fused upstream of the coding sequence of appA. We show that $S P O$ promoter directed high-level phytase expression in various organs of transgenic potato. Expression of a secretory phytase not only improved $\mathrm{P}$ acquisition when phytate was supplied as the sole $\mathrm{P}$ source but also increased tuber size, number and yield. We also show that supplement of the potato-produced phytase improved the bioavailability of phytate-P to weanling pigs.

\section{Materials and methods}

Plant material

Potato cultivar Solanum tuberosum L. cv. Kennebec was used in this study. Potato stem segments of $2-3-\mathrm{cm}$ long were cultured for initiation of seedlings on MS agar medium (Murashige-Skoog basal salts, Sigma) and for production of microtubers on a modified MT agar medium (Wang and $\mathrm{Hu}$ 1982) containing MS salts with $5 \mathrm{mg} / \mathrm{l}$ 6-BAP and $8 \%$ sucrose. MS salts contain phosphate $(170 \mathrm{mg} / \mathrm{l}$ or $1.25 \mathrm{mM}$ $\mathrm{KH}_{2} \mathrm{PO}_{4}$ ). Potato cultures were maintained at $25^{\circ} \mathrm{C}$ with a 16-h daily light.

\section{Plasmid construction}

The method for plasmid construction has been described previously in two patent applications (Yu 2003a, b). Briefly, a DNA fragment containing 1131-bp SPO promoter plus a 63-bp signal peptide sequence and an extra 48-bp sequence were PCR-amplified using sweet potato genomic DNA as a template and Spo5' (5'-CCCAAGCTTTGCCAAACAGAG CCTA-3') and Sposp3' (5'-GGAATTCGGCGGGTTCGT GTGTGGT- $3^{\prime}$ ) as primers. Spo5 ${ }^{\prime}$ and Spop $3^{\prime}$ primers were designed based on the genomic DNA sequence of SPO-AI (Hattori and Nakamura 1988). The nopaline synthase gene (Nos) terminator was PCR-amplified using pBI221 (Clontech) as a DNA template and oligonucleotides $5^{\prime}$-TCC GAGCTGCAGATCGTTCAAACATTT- ${ }^{\prime}$ and $5^{\prime}$-AGCGA GCTCGATCGATCTCTAGACAT- $3^{\prime}$ as primers. The 1.24$\mathrm{kb}$ E. coli phytase gene appA was PCR-amplified using plasmid pET-appA (Golovan et al. 2000) as a DNA template and appA $5^{\prime}\left(5^{\prime}\right.$-AAAGAATTCCAGAGTGAGCCGGAG CTGAAGCT- $\left.3^{\prime}\right)$ and appA $3^{\prime}$ (5'-AAACTGCAGTTAC AAACTGCACGCCGGTAT- $3^{\prime}$ ) as primers.

The SPO promoter was digested with HindIII and EcoRI and inserted into same sites in pBluescript (Strategene), generating pBS-Sposp. The Nos terminator was digested with $P s t \mathrm{I}$ and $X b a \mathrm{I}$ and fused downstream of the $S P O$ promoter in pBS-Sposp, generating pBS-Sposp-Nos. The appA gene was digested with EcoRI and PstI and inserted into same sites in pBS-Sposp-Nos, generating pBS-Sposp-appANos. The Sposp-appA-Nos fusion gene was excised from pBS-Sposp-appA-Nos with $\mathrm{XbaI}$ and HindIII and inserted into same sites in the binary vector pCAMBIA2301 (a gift from Richard A. Jefferson, CAMBIA, Australia), generating pSpo-appA (Fig. S2).

\section{Potato transformation}

The method for potato transformation has been described previously in two patent applications ( $\mathrm{Yu} \mathrm{2003a,} \mathrm{b).}$ Briefly, cultured potato microtubers were sliced into 2-mm thick discs. Discs were placed on 3C5ZR agar medium (Sheerman and Bevan 1988), co-cultured with $5 \mathrm{ml}$ of Agrobacterium in 3C5ZR liquid medium, and incubated at $26^{\circ} \mathrm{C}$ for $15 \mathrm{~min}$. The microtuber discs along with Agrobacterium were transferred to 3C5ZR-AS agar medium [3C5ZR medium plus $100 \mu \mathrm{M}$ acetosyringon (Aldrich) and $3 \mathrm{~g} / \mathrm{l}$ phytagel (Sigma), pH 5.2] and incubated at $28^{\circ} \mathrm{C}$ in the dark for $72 \mathrm{~h}$. The infected microtuber discs were washed three times with 3C5ZR liquid medium containing $100 \mathrm{mg} / \mathrm{l} \mathrm{ticarcillin} / \mathrm{clavulanic}$ acid (timenten) (Duchefa), blotted dry on sterile filter papers, and transferred to 3C5ZR agar medium containing $100 \mathrm{mg} / \mathrm{l}$ each of kanamycin (Sigma) and timenten and incubated at $26^{\circ} \mathrm{C}$ with 16-h daily light for selection of transformants. The tissues were subcultured at weekly intervals. After several weeks, young shoots formed from the inoculated microtuber discs were transferred to MS agar medium containing $100 \mathrm{mg} / \mathrm{l}$ each of kanamycin and timenten and incubated at $26^{\circ} \mathrm{C}$ with 16-h daily light. Regenerated seedlings were transferred to soil when $10-15-\mathrm{cm}$ high and incubated at $26^{\circ} \mathrm{C}$ with 16-h daily light for further growth. Non-transformants (NTs) are not transgenic lines but passed through same tissue culture steps as transgenic lines.

\section{Overexpression of phytase in Pichia pastoris} and preparation of antibodies

The method for overexpression of phytase and preparation of anti-phytase antibodies have been described previously in two patent applications (Yu 2003a, b). appA was PCRamplified using a pET-appA (Golovan et al. 2000) as the DNA template and oligonucleotides 5'-GCGAATTCCA GAGTGAGCCGGAGCTG- $3^{\prime}$ and $5^{\prime}$-GCTCTAGATACG CATTAGACAGTTCTTCGTT- $3^{\prime}$ as primers. The PCR products were digested with $E c o$ RI and $X b a \mathrm{I}$ and inserted into same sites in $\mathrm{pICZ} \alpha \mathrm{A}$ (Invitrogen), generating pPIC$\mathrm{Z} \alpha \mathrm{A}$-appA in which the appA was preceded by an alcohol 
oxidase (AOX) promoter and $\alpha$-factor signal peptide. pPICZ $\alpha$ A-appA was amplified in E. coli strain DH5 $\alpha$ (Promega) using low salt LB broth (1\% tryptone, $0.5 \%$ sodium chloride, $0.5 \%$ yeast extract, $\mathrm{pH} 7.5$ ) supplemented with Zeocin $(25 \mu \mathrm{g} / \mathrm{ml})$ (Invitrogen). pPICZ $\alpha \mathrm{A}$-appA was linearized by $P m e \mathrm{I}$ and transferred into $P$. pastoris strain KM71 (Invitrogen) by electroporation. The transformed cells were cultured on YPD ( $1 \%$ yeast extract, $2 \%$ peptone, $2 \%$ dextrose, $1 \mathrm{M}$ sorbitol, pH 7.5) plus zeocin $(100 \mu \mathrm{g} /$ $\mathrm{ml}$ ) agar plate at $30^{\circ} \mathrm{C}$ for 3 days. The Zeocin-resistant yeast colony was incubated in BMGY medium $[1 \%$ yeast extract, $2 \%$ peptone, $1 \mathrm{mM}$ potassium phosphate, $\mathrm{pH} 6.0$, $1.34 \%$ yeast nitrogen bath (Invitrogen), $4 \times 10^{-5} \%$ biotin, and $1 \%$ glycerol] for enrichment of cell mass and then in BMMY medium (same ingredients as BMGY medium except that $1 \%$ glycerol was replaced with $0.5 \%$ methanol) for induction of phytase expression. All media were prepared as suggested in the Easy Select Pichia Expression Kit (Invitrogen). Phytase was the major protein secreted into the culture medium and could be recovered by lyophilization of the culture medium. One hundred micrograms of purified phytase was injected into a New Zealand White rabbit successively at 4-6 intervals for generation of polyclonal antibodies.

\section{DNA gel blot analysis}

Genomic DNA was isolated from potato leaves as decribed (Sheu et al. 1996). DNA samples $(20 \mu \mathrm{g})$ were digested with EcoRI, separated by $0.8 \%$ agarose gel electrophoresis, and transferred to nylon membranes (MSI). The membrane was hybridized with ${ }^{32} \mathrm{P}$-labeled appA DNA as a probe.

\section{Phytase activity assay}

Protein extract was prepared from microtubers, leaves, stems and tubers as described ( $\mathrm{Li}$ et al. 1997b) and the phytase activity was determined as described (Shimizu 1992). Briefly, $150 \mu \mathrm{l}$ of extracted proteins were incubated with $600 \mu \mathrm{l}$ of $1.5 \mathrm{mM}$ sodium phytate at $37^{\circ} \mathrm{C}$ for $15 \mathrm{~min}$. The reaction was stopped by adding $750 \mu \mathrm{l}$ of 5\% trichloroacetic acid. Following production of phosphomolybdate with $1.5 \mathrm{ml}$ of coloring reagent, the liberated inorganic orthophosphate $\left(\mathrm{P}_{\mathrm{i}}\right)$ was photometrically measured at $700 \mathrm{~nm}$. The coloring reagent was prepared freshly by mixing four volumes of $1.5 \%$ ammonium molybdate solution in $5.5 \%$ sulfuric acid and one volume of $2.7 \%$ ferrous sulfate solution. One unit of phytase activity was defined as the amount of enzyme that frees $1 \mu$ mole inorganic $P_{i}$ from $1.5 \mathrm{mM}$-sodium phytate/min at $\mathrm{pH} 4.5$ and $37^{\circ} \mathrm{C}$. Protein concentration of total soluble proteins was determined by the Bio-Rad Coomassie Protein assay kit.
Analysis of optimal $\mathrm{pH}$ and temperature for phytase activity

Phytase activity was assayed over a $\mathrm{pH}$ range from 1.0 to 6.0 at $37^{\circ} \mathrm{C}$ as described above. Buffer systems used to cover the $\mathrm{pH}$ range were: $100 \mathrm{mM}$ Glycine- $\mathrm{HCl}$ for $\mathrm{pH} 1.0$ to $3.5 ; 100 \mathrm{mM}$ sodium acetate for $\mathrm{pH} 3.5$ to 6.0 . For analysis of optimal temperatures for phytase activity, proteins in $100 \mathrm{mM}$ sodium acetate, $\mathrm{pH} 5.0$, were analyzed from 35 to $75^{\circ} \mathrm{C}$.

\section{Protein gel blot analysis}

Total proteins were extracted from potato tissues using an extraction buffer $[50 \mathrm{mM}$ Tris- $\mathrm{HCl}$ ( $\mathrm{pH} 8.8), 1 \mathrm{mM}$ EDTA, $10 \%$ glycerol, $1 \%$ Triton X-100, $10 \mathrm{mM} \beta$-mercaptoethanol, and $0.1 \%$ sarkosyl]. Protein gel blot analysis was performed with an ECL Western blotting analysis system (Amersham Pharmacia).

Phenotypic characterization of transgenic plants in field

Plantlets of NT and three independent transgenic lines were grown in commercial compost (Potgrond H, Klasmann, Germany) in the farmland of the Taiwan Agricultural Research Institute, Wufeng, Taichung, Taiwan. The compost (70 1/pack) was composed of black sphagnum peat and white peat and supplemented with the following fertilizers: $\mathrm{N}, 160-260 \mathrm{mg} / \mathrm{l} ; \mathrm{P}_{2} \mathrm{O}_{5}, 180-280 \mathrm{mg} / \mathrm{l} ; \mathrm{K}_{2} \mathrm{O}, 200-350 \mathrm{mg} / \mathrm{l}$; $\mathrm{Mg}, 80-150 \mathrm{mg} / \mathrm{l} ; \mathrm{KCl}, 1.5 \mathrm{~g} / \mathrm{l}$. Before planting of potato seedlings, $1 \%(\mathrm{w} / \mathrm{v})$ of chicken excrement was added to the compost. The $\mathrm{P}$ content in the chicken excrement was $10-15 \mathrm{~g} / \mathrm{kg}$, consequently, the final $\mathrm{P}$ content in the compost was $100-150 \mathrm{mg} / \mathrm{l}$. The experimental design was a randomized complete block with four replicates. The plant height, stem number, plant dry weight, and tuber weight and numbers were determined. Yield per plant was determined 120 days after transplanting of plantlets into soil. Potato tubers at different sizes (with weights ranging from $2 \mathrm{~g}$ to $300 \mathrm{~g}$ per tuber) were harvested and analyzed for phytase activity.

Chlorophyll $\mathrm{a}$ and $\mathrm{b}$ and carotenoid determination

Fresh leaves were collected from NT and transgenic potato grown in the compost as described above in the farmland and fresh weight determined. These leaves were then ground with liquid nitrogen in a mortar with pestle. Pigments were extracted with $80 \%$ acetone, and light absorption at 331, 470, 552.4, and $556.2 \mathrm{~nm}$ were determined using a UV/Visible spectrophotometer. Concentrations of chlorophyll $a$ and $b$ and total carotenoids were calculated as described (Lichtenthaler 1987). 
Free P assay

Pi contents were analyzed as described (Chiou et al. 2006) with minor modifications. Fresh tissues were frozen with liquid nitrogen and homogenized with extraction buffer (10 mM Tris, $1 \mathrm{mM}$ EDTA, $100 \mathrm{mM} \mathrm{NaCl,} 1 \mathrm{mM}$ $\beta$-mercaptoethanol, and $1 \mathrm{mM}$ phenylmethylsulfonyl fluoride, $\mathrm{pH} 8.0$ ) at a ratio of $1 \mathrm{mg}$ of sample (fresh weight) to $10 \mu \mathrm{l}$ of extraction buffer. Samples were centrifuged at $13,000 \mathrm{~g}$ for $5 \mathrm{~min}$, and $60 \mu \mathrm{l}$ of the supernatant was transferred to a 96-wells plate and incubated at $42^{\circ} \mathrm{C}$ for $30 \mathrm{~min}$. Each sample solution was added with $140 \mu \mathrm{l}$ of assay solution $\left(0.35 \% \mathrm{NH}_{4} \mathrm{MoO}_{4}, 0.86 \mathrm{~N} \mathrm{H}_{2} \mathrm{SO}_{4}\right.$, and $1.4 \%$ ascorbic acid) and incubated at $42^{\circ} \mathrm{C}$ for $30 \mathrm{~min}$. Pi content was measured at $A_{820}$.

Phytase activity in dry tuber slices for animal feeding tests

Tubers of NT and transgenic potato line 2-1 were sliced and dried at $37^{\circ} \mathrm{C}$ for $72 \mathrm{~h}$. Dried samples were ground to powder and phytase activity was determined as described above. Phytase activity in dried NT and transgenic potato tuber slices were 0.1 and $50 \mathrm{U} / \mathrm{g}$, respectively.

\section{Animal feeding tests}

Forty crossbred pigs (approximately $30 \mathrm{~kg}$ body weight each) were randomly allotted to five group treatments, with 8 pigs per treatment and 4 pigs (half barrows and half gilts) per pen. Treatments consisted of dietary P levels of 0.62 and $0.56 \%$ in control diets or 0.51 and $0.42 \%$ in low $\mathrm{P}$ diets for growing and finishing stages (Table S1), respectively. Diets were formulated to have grower and finisher $\mathrm{Ca} / \mathrm{P}$ ratio of 1.27 for the control group and ratios of 1.53 and 1.69 as grower and finisher, respectively, for the low $\mathrm{P}$ group. The commercial phytase, a recombinant phytase encoded by Aspergillus niger phyA, was purchased from BASF (Mount Olive, NJ) with a specific activity of 5,000 U/g product. Microbial phytase was added as a supplement to the low $\mathrm{P}$ diet at $500 \mathrm{U} / \mathrm{kg}$ of feed as suggested by the manufacturer. The potato-produced phytase was supplemented to the low $\mathrm{P}$ diet at two doses of 50 and $150 \mathrm{U} / \mathrm{kg}$ of feed. Apart from P, other nutrients were kept constant for all treatments.

Body weight and feed consumption of pigs were recorded every 4 weeks from the start of the trail to calculate average daily gain, average daily feed intake and feed efficiency. Serum and feces were collected at the beginning and at the end of the trial for $\mathrm{P}$ analysis. Serum $\mathrm{P}$ contents were determined by an automated chemistry analyzer (Kodak Ektachem DT System), and fecal P contents were measured by AOAC method (AOAC 1984). After the trial, the third and forth metacarpal were colleted from all pigs for strength determination (Instron Testing Machine, Instron Corp., High Wycombe, Bucks. UK). Data were analyzed as a completely random design with two replicates using the GLM procedure in SAS software (SAS 1989).

\section{Results}

The sweet potato sporamin promoter is active in various organs of transgenic potato

In the present study, plasmid pSpo-appA containing appA under the control of SPO promoter was used for potato transformation, and 15 putative independent transgenic lines were obtained. pSpo-appA also contains a CaMV35SGUS cDNA fusion gene derived from pCAMBIA2301 (Fig. S1). GUS activity was detected in leaves of all transgenic lines, indicating successful transformation of potato (data not shown). The nucleotide sequences of $S P O$ and SPO-Al promoters are highly homologous to each other, but there are deletion, insertion and substitution differences between the two promoters (Fig. S2). To determine whether the SPO promoter is capable of directing phytase expression in transgenic potato, transgenic and non-transgenic potato phytase activities were compared. All transgenic lines and non-transformants (NTs) were cultured in MT medium until microtubers formed. Total proteins were extracted from microtubers and phytase activity analyzed. Phytase activity was barely detectable (6-28 U/g TSP) in microtubers of NTs but was readily detectable (340-630 U/g of TSP) in microtubers of transgenic lines (Fig. 1). This result indicates that the SPO promoter is capable of controlling phytase expression in transgenic potato microtubers.

To determine whether the copy number of transgenes affected the expression levels of phytase in transgenic potato, genomic DNA was extracted from leaves and subjected to DNA gel blot analysis. The transgene copy number ranged from 1 to 3 (Fig. S3), which did not correlate with the phytase activity in transgenic potato microtubers (Fig. 1).

To determine whether $S P O$ promoter is active in various organs of transgenic potato, three transgenic lines 1-1, 2-1, and 7-1 were selected for further analysis. Total proteins were extracted from leaves, stems, roots and microtubers of cultured transgenic potato plants and phytase activity analyzed. Phytase activity was not detected in NTs but was detected in the range of $36,000-58,000 \mathrm{U} / \mathrm{kg}$ in leaves, $26,000-50,000 \mathrm{U} / \mathrm{kg}$ in stems, 4000-10,000 U/kg in roots, and 34,000-38,000 U/kg in microtubers of transgenic lines (Fig. 2a). Transgenic potato seedlings were then transferred to pot soil in a growth chamber and allowed to grow for three months. Total proteins were extracted from leaves, stems and 


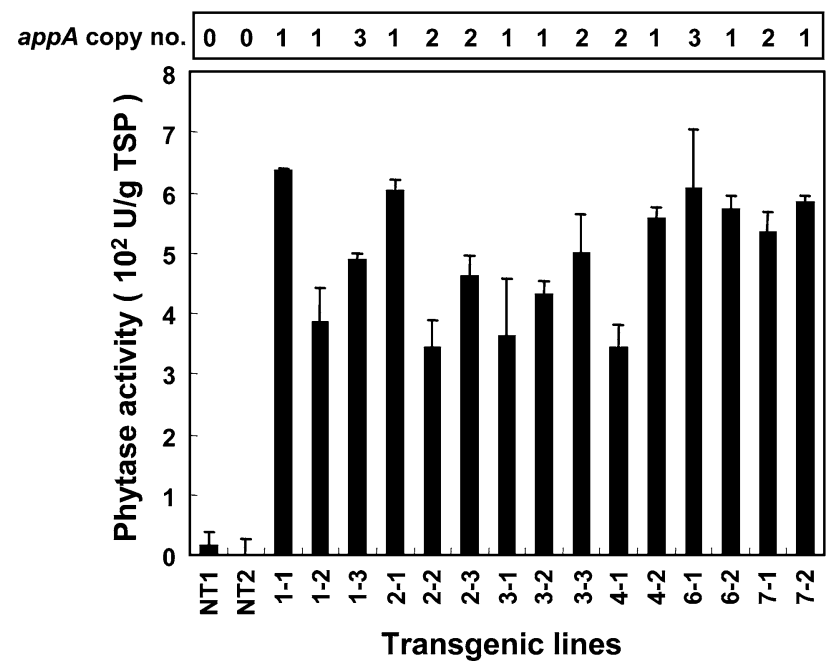

Fig. 1 The sweet potato sporamin promoter directs phytase expression in microtubers of transgenic potato. Microtubers of three individual tissue-cultured plants, from each of 15 independent transgenic lines, were collected for phytase activity assays. Error bars indicate the standard deviation of phytase activity in microtubers of three plants. Phytase activity is expressed as units (U) per $g$ of total soluble proteins (TSP). NT: non-transformant. Copy numbers of appA for each transgenic line are indicated on the top of the bar graph

tubers and phytase activity analyzed. Phytase activity was not detected in NTs but was detected in the range of 8,000 $20,000 \mathrm{U} / \mathrm{kg}$ in leaves, $6,000-14,000 \mathrm{U} / \mathrm{kg}$ in stems and $40,000-50,000 \mathrm{U} / \mathrm{kg}$ in tubers of transgenic lines (Fig. 2b). These results indicate that the sporamin promoter confers phytase expression in various organs of transgenic potato grown either in culture medium or in soil.

To estimate the yield of recombinant phytase produced in transgenic potato, total proteins were extracted from leaves, stems and tubers of transgenic lines 1-1, 2-1 and 7-1 and subjected to protein gel blot analysis using anti-phytase antibodies. A series of known amounts of purified recombinant appA expressed in Pichia, serving as standards, were loaded along with samples from transgenic potato in the protein gel blot analysis. Levels of phytase expressed in transgenic potato were then quantified by comparison with the purified phytase standards. The yields of phytase in leaves and stems were approximately $4.2-7.4 \%$ of TSP, and those in tubers were approximately $2.4-3.8 \%$ of TSP (Fig. 3).

The sporamin promoter confers high-level phytase expression in transgenic potato tubers of different sizes

Normally a potato plant produces tubers of different sizes. To determine whether phytase expression varied in different size tubers, tubers with sizes ranging from $2 \mathrm{~g}$ to $300 \mathrm{~g}$ were collected from three plants each of three transgenic lines (1-1, 2-1 and 7-1) and classified into 10
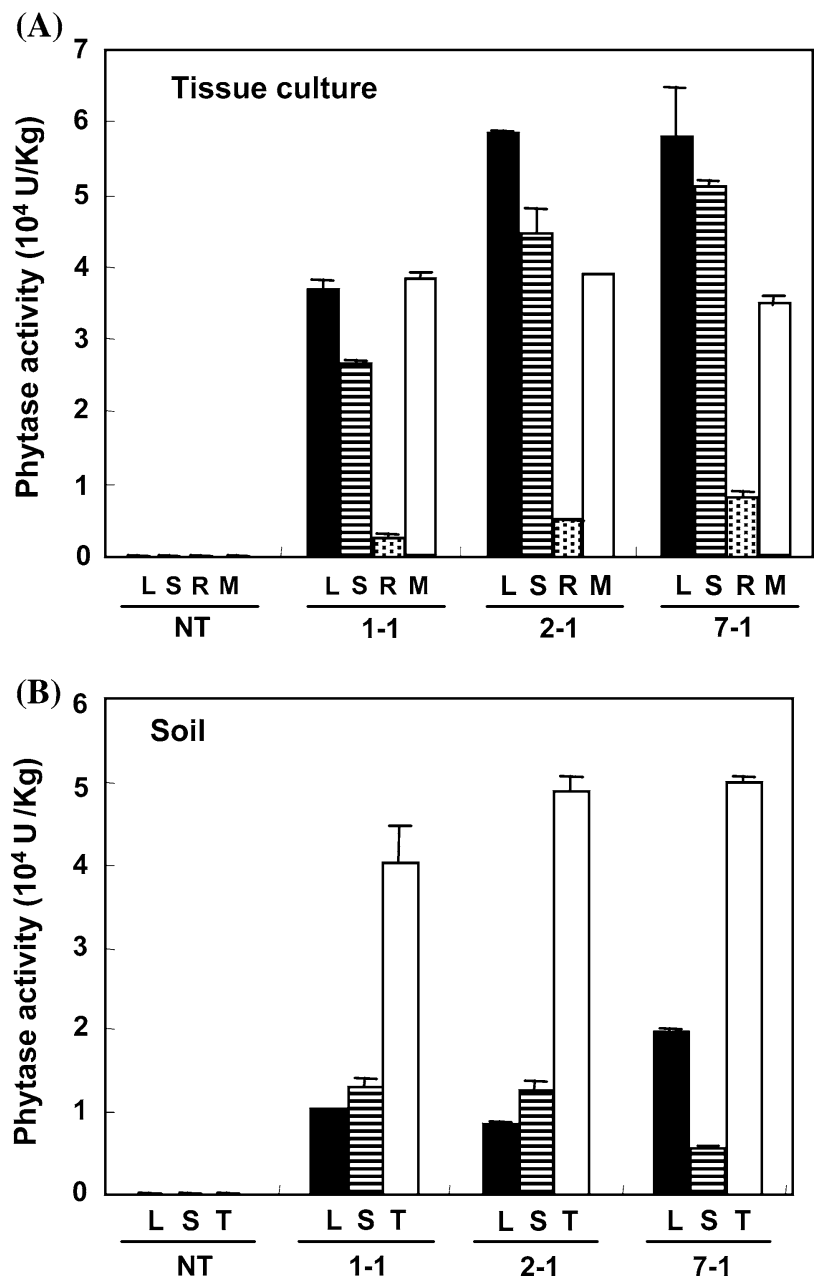

Fig. 2 The sporamin promoter is active in various organs of transgenic potato. (a) Leaves $(\mathrm{L})$, stems $(\mathrm{S})$, roots $(\mathrm{R})$ and microtubers (M) of three tissue-cultured plants, from each of 3 transgenic lines and non-transformant (NT), were collected for phytase activity assays. (b) Leaves (L), stems (S), and tubers (T) of three soil-grown plants, from each of 3 transgenic and 1 non-transformant (NT) lines, were collected for phytase activity assays. Error bars indicate the standard deviation of phytase activity in each organ of three plants. Phytase activity is expressed as units (U) per $\mathrm{Kg}$ of fresh weight of organ assayed

groups (Figs. 4a, b). Phytase activities of most tubers were similar in different groups (in the range of 38,000 $59,000 \mathrm{U} / \mathrm{kg}$ in line $1-1$ and $43,000-56,000 \mathrm{U} / \mathrm{kg}$ in line $7-1)$. Phytase activity in line 2-1 had approximately $20 \%$ lower activity at groups 1-6 (ranging $28,000-37,000 \mathrm{U} / \mathrm{kg}$ ) compared to groups 7-10 (ranging 46,000-55,000 U/kg) (Fig. 4c).

Phytase expressed in transgenic potato tubers is active over broad $\mathrm{pH}$ and temperature ranges

To determine the optimal $\mathrm{pH}$ for phytase activity in transgenic potato, total proteins were extracted from tubers 

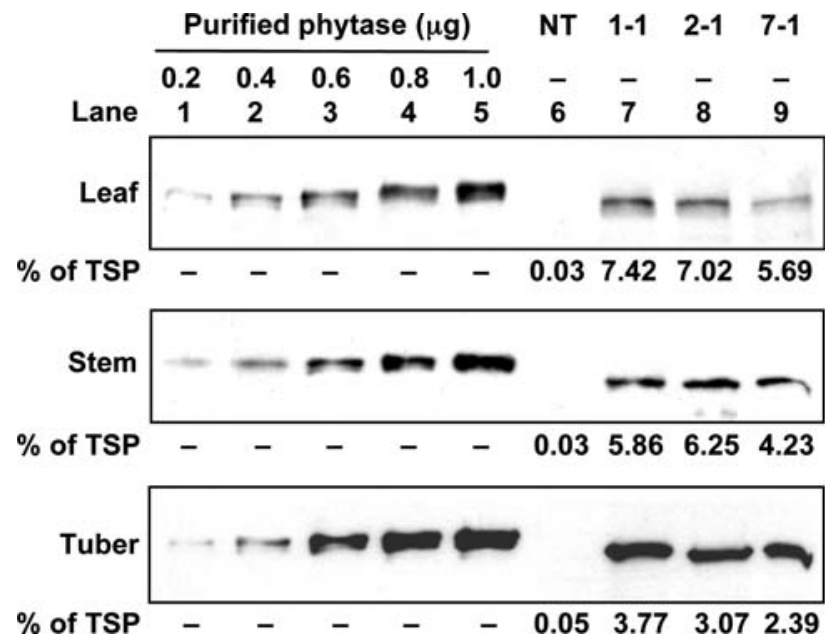

Fig. 3 The sporamin promoter confers high-level phytase expression in various organs of transgenic potato. Total proteins were extracted from leaves, stems, and tubers of soil-grown plants of 3 transgenic and 1 non-transformant (NT) lines for protein gel blot analysis. Amount of total leaf, stem and tuber proteins loaded in each of lanes 6-9 was 10, 10 and $25 \mu \mathrm{g}$, respectively. Phytase expressed in Pichia was purified and loaded in various known amounts for protein gel blot analysis. Levels of phytase expressed in transgenic potato were quantified by comparison with the purified phytase standards and expressed as \% of total soluble proteins (TSP)

of transgenic line 2-1. Optimal $\mathrm{pH}$ for phytase activity was measured at $37^{\circ} \mathrm{C}$, the temperature in animal gastrointestinal tracks. Phytase activity reached peaks at $\mathrm{pH} 2.5$ and 5.5 (Fig. 5a). At least $60 \%$ of phytase activity was maintained at $\mathrm{pH} 1.5-6.0$.

Phytase active at high temperature may facilitate feed processing. To determine the optimal temperature for phytase activity in transgenic potato, total proteins were extracted from tubers of transgenic line 2-1. The optimal temperatures for phytase activity were between $50^{\circ} \mathrm{C}$ and $60{ }^{\circ} \mathrm{C}$, and $80 \%, 60 \%$ and $50 \%$ of phytase activity were maintained at temperatures of $65^{\circ} \mathrm{C}, 70^{\circ} \mathrm{C}$ and $75^{\circ} \mathrm{C}$, respectively (Fig. 5b).

Overexpression of phytase increases leaf pigmentation and tuber yield of transgenic potato

Transgenic lines 1-1, 2-1, and 7-1 were grown in fields between October 2003 to January 2004 and October 2004 to January 2005 (two winter seasons). Field trials were terminated before plants were completely senescent. Significant differences in phenotypes between transgenic lines and NTs were observed. First, the leave color (Fig. 6a) and crude leaf extracts (Fig. 6b) of transgenic potato were deeper green than NTs. Photometric pigment measurement revealed that contents of chlorophylls $\mathrm{a}$ and $\mathrm{b}$ and carotenoids (including xanthophylls and $\beta$-carotene) were $2-3$ times higher in transgenic lines than in NTs (Fig. 6c).
(A) $\mathrm{cm}$
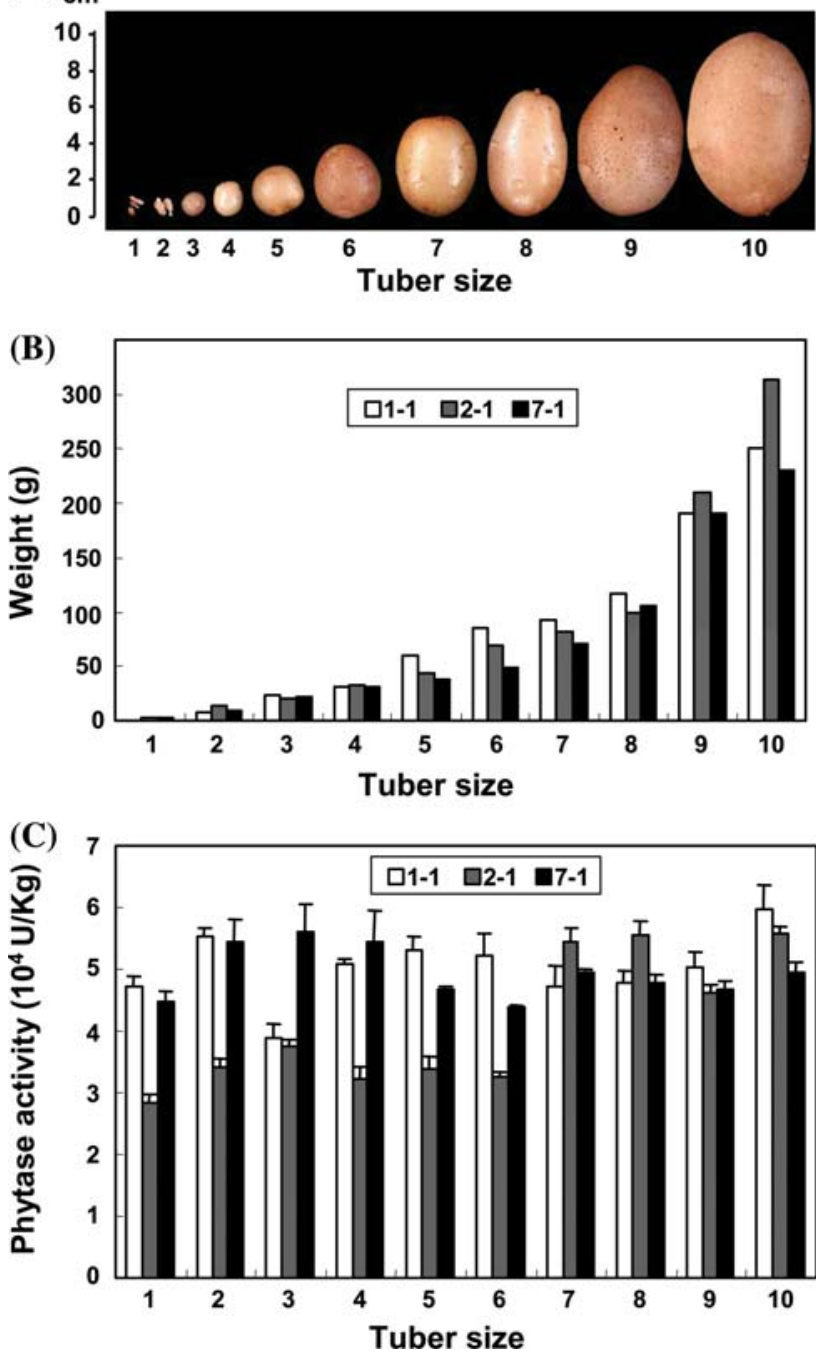

Fig. 4 The sporamin promoter confers high-level phytase expression in transgenic potato tubers of different sizes. (a) Tubers of soil-grown transgenic potato plants were assigned to 10 size groups. (b) Fresh weights of transgenic potato tubers of different size groups. (c) Phytase activities of tubers of 3 plants, from each of 3 transgenic lines, of different size groups were determined. Phytase activity is expressed as units (U) per $\mathrm{Kg}$ of tuber fresh weight. Error bars indicate the standard deviation of phytase activity recorded in tubers of three plants

Second, the average fresh weight of tubers per plants increased significantly in transgenic lines $2-1$ and $7-1$, ranging from $7 \%(P<0.05)$ to $14 \%(<0.01)$ in year 2003 , and in all transgenic lines ranging from $16 \%$ to $22 \%$ $(P<0.01)$ in year 2004 field trials as compared with NTs (Table 1). Transgenic and NT plants grown in 2003 were derived from seedlings propagated in culture media while those grown in 2004 were derived from cuttings of tubers propagated in 2003 and had stronger seedling vigor. Therefore, the average fresh weight of tubers per plant was 2-fold higher for the field trial carried out in 2004 than in 2003. 

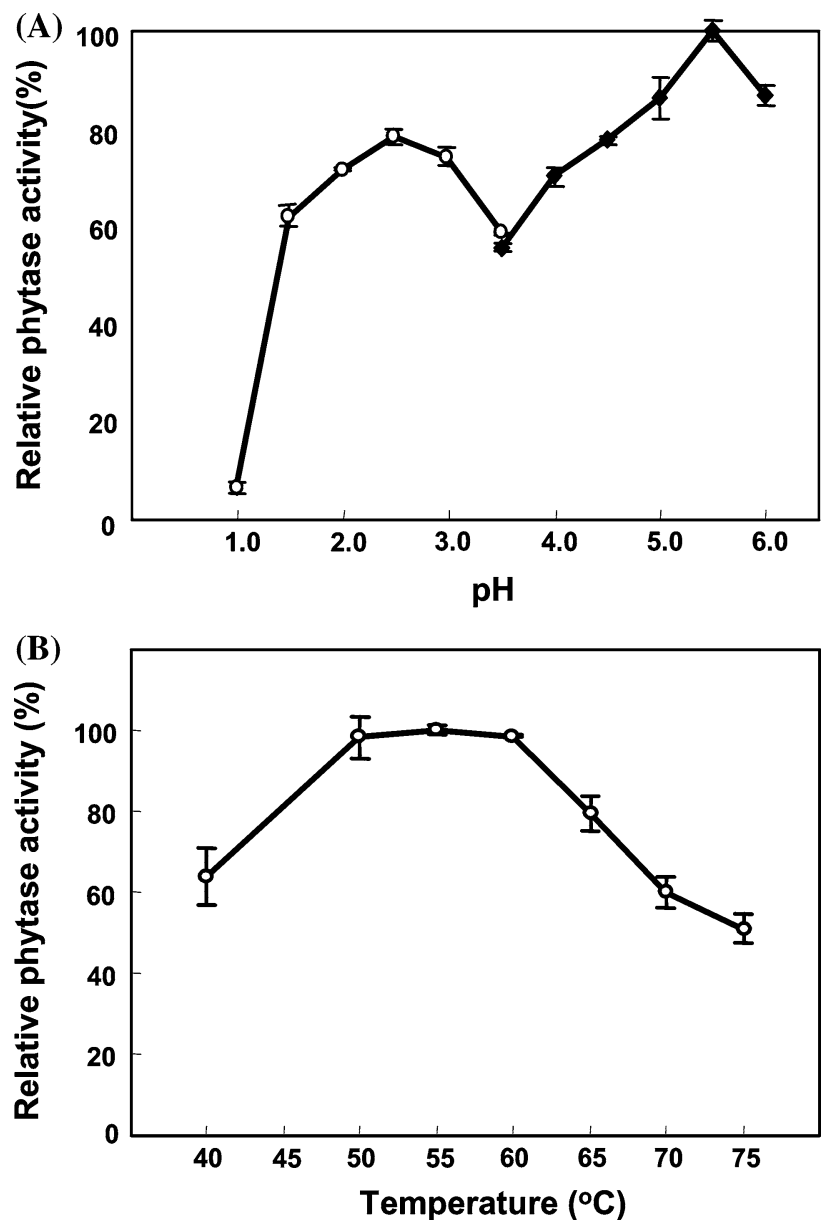

Fig. 5 Phytase expressed in transgenic potato tubers is active over broad $\mathrm{pH}$ and temperature ranges. (a) $\mathrm{pH}$ profile of phytase activity expressed in transgenic potato tubers. Phytase activity in 3 tubers of transgenic line 2-1 was determined over a $\mathrm{pH}$ range of 1.0-3.5 using Glycine- $\mathrm{HCl}$ buffer and 3.5-6.0 using sodium acetate buffer. (b) Temperature profile of phytase activity expressed in transgenic potato tubers. Phytase activity in 3 tubers of transgenic line 2-1 was determined between 40 and $75^{\circ} \mathrm{C}$

Third, the tuber number per plant increased in transgenic lines as compared with NTs, ranging from 1.4- to 1.9-fold $(P<0.05)$ in two field trials (Table 2). Tubers were further classified into three groups based on their fresh weights, and relative number of tubers in each group was compared. Transgenic lines produced more large-size tubers than NTs. In year 2003, ratios of tubers with weights 50-100 g each were significantly higher for NT than transgenic lines 1-1 and 2-1 $(P<0.01)$; in contrast, ratios of tubers with weight $>100 \mathrm{~g}$ each were significantly higher for all transgenic lines than NTs $(P<0.01)$ (Table 2 , upper panel). In year 2004 , ratios of tubers with weights $<50 \mathrm{~g}$ and $50-100 \mathrm{~g}$ each were significantly higher for NTs than transgenic lines $(P<0.01)$; in contrast, ratios of tubers with weights $>100 \mathrm{~g}$ were significantly higher for transgenic lines than

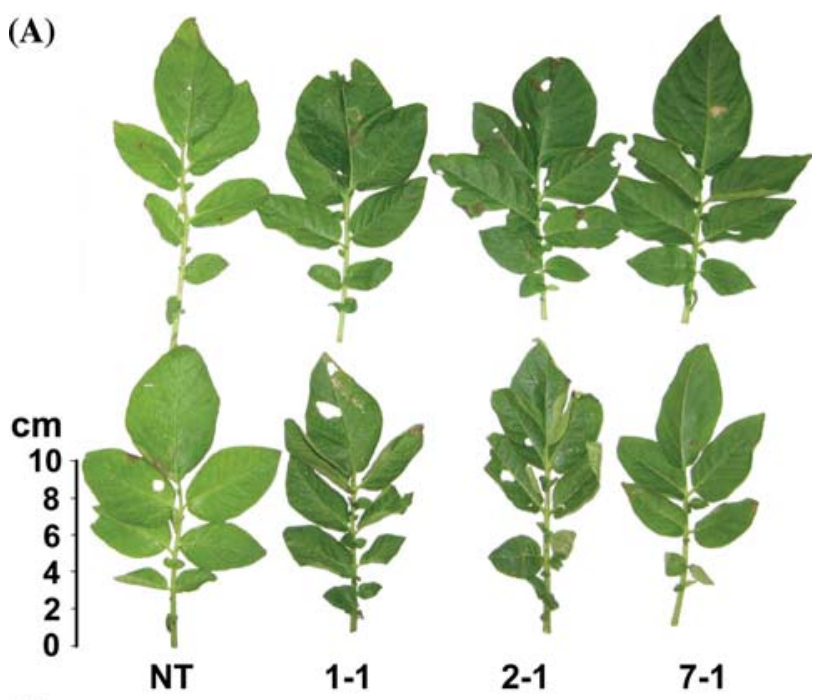

(B)
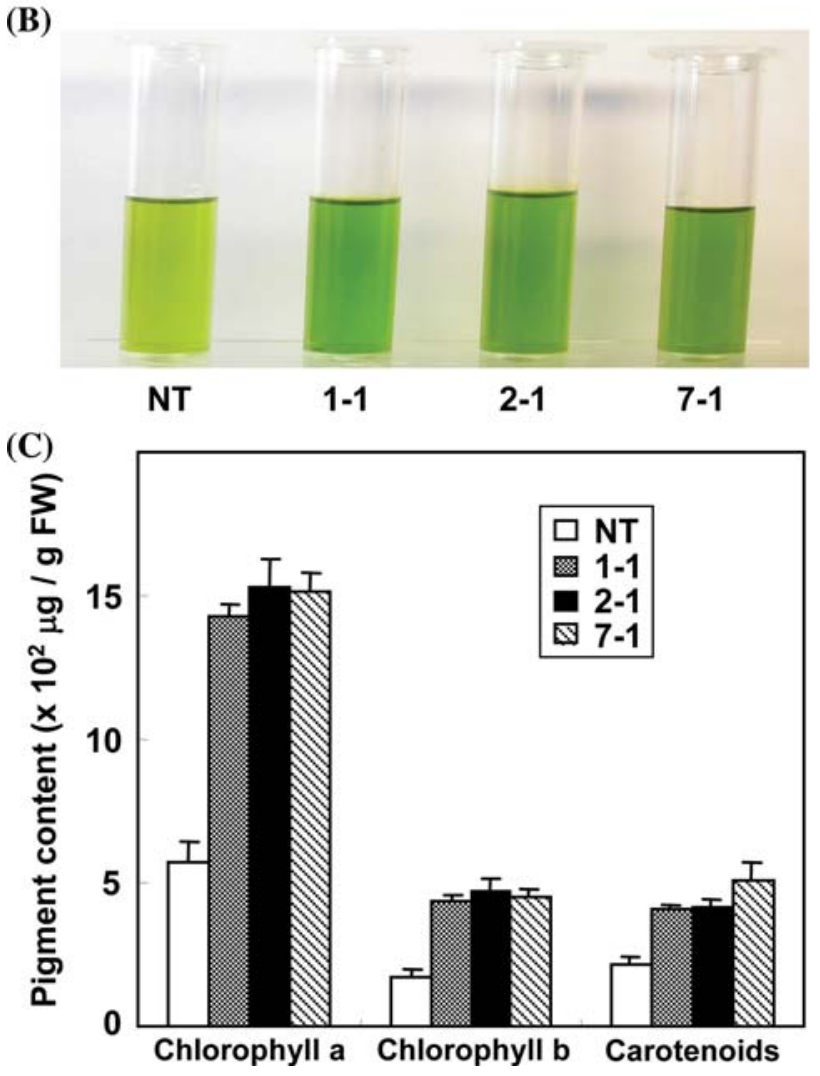

Fig. 6 Overexpression of phytase increases leaf pigmentation of transgenic potato. (a) Leaves from two plants each of three transgenic lines and non-transformant (NT). Leaves were collected from plants after being grown in field for two months. Some leaves were slightly distorted or dried during transportation from field to laboratory. (b) Pigment extracts from leaf samples shown in (a). (c) Level of three pigments, chlorophyll a, chlorophyll $\mathrm{b}$ and carotenoids, present in samples shown in (b) were measured photometrically. FW, fresh weight

NTs (Table 2, lower panel). These studies indicate overexpression of phytase enhanced production and growth of tubers. 
Table 1 Overexpression of phytase increases yield of potato tubers
FW, fresh weight

**** Comparisons significantly different to non-transformant (NT) by Dunnett's $t$-tests at the 0.05/0.01 level

Table 2 Overexpression of phytase increases number and size of potato tubers

\begin{tabular}{cllll}
\hline Line & $\begin{array}{l}\text { No. of } \\
\text { plant }\end{array}$ & $\begin{array}{l}\text { Total yield } \\
\text { of tuber }(\mathrm{g})\end{array}$ & $\begin{array}{l}\text { Average tuber } \\
\text { FW per plant }(\mathrm{g})\end{array}$ & $\begin{array}{l}\text { Increase in tuber } \\
\text { FW per plant }(\%)\end{array}$ \\
\hline 2003 & & & & \\
$\mathrm{NT}$ & 48 & 18109 & $374.4 \pm 55.2$ & 100 \\
$1-1$ & 47 & 19233 & $396.4 \pm 59.8$ & 106 \\
$2-1$ & 48 & 20583 & $428.0 \pm 10.8^{* *}$ & $114^{* *}$ \\
$7-1$ & 41 & 16461 & $401.8 \pm 41.5^{*}$ & $107^{*}$ \\
2004 & & & & 100 \\
NT & 70 & 55748 & $774.3 \pm 150.7$ & $119^{* *}$ \\
$1-1$ & 70 & 64232 & $917.6 \pm 142.1^{* *}$ & $122^{* *}$ \\
$2-1$ & 68 & 66221 & $946.0 \pm 90.7^{* *}$ & $116^{* *}$ \\
$7-1$ & 72 & 61310 & $901.6 \pm 71.0^{* *}$ & \\
\hline
\end{tabular}

\begin{tabular}{|c|c|c|c|c|c|c|}
\hline \multirow[t]{2}{*}{ Line } & \multirow{2}{*}{$\begin{array}{l}\text { No. of } \\
\text { plant }\end{array}$} & \multirow{2}{*}{$\begin{array}{l}\text { Total no. } \\
\text { of tubers }\end{array}$} & \multirow{2}{*}{$\begin{array}{l}\text { No. of tubers } \\
\text { per plant }\end{array}$} & \multicolumn{3}{|c|}{ Ratio $(\%)$ of tubers with weight } \\
\hline & & & & $<50 \mathrm{~g}$ & $50-100 \mathrm{~g}$ & $>100 \mathrm{~g}$ \\
\hline \multicolumn{7}{|l|}{2003} \\
\hline NT & 48 & 46 & 1 & $28.7 \pm 15.5$ & $30.9 \pm 12.9$ & $41.3 \pm 9.2$ \\
\hline $1-1$ & 47 & 69 & $1.5^{*}$ & $22.9 \pm 5.1$ & $24.0 \pm 14.3^{* *}$ & $53.1 \pm 8.9^{* *}$ \\
\hline $2-1$ & 48 & 89 & $1.9^{*}$ & $12.6 \pm 2.1$ & $22.5 \pm 8.8^{* *}$ & $64.9 \pm 10.8 * *$ \\
\hline $7-1$ & 41 & 58 & $1.4^{*}$ & $24.3 \pm 10.8$ & $24.4 \pm 10.1$ & $51.3 \pm 13.5^{* *}$ \\
\hline \multicolumn{7}{|l|}{2004} \\
\hline NT & 70 & 162 & 2.3 & $22.6 \pm 3.4$ & $36.1 \pm 2.5$ & $41.2 \pm 5.8$ \\
\hline $1-1$ & 70 & 275 & $3.9^{*}$ & $8.8 \pm 2.9^{* *}$ & $25.7 \pm 5.9^{* *}$ & $65.5 \pm 8.0^{* *}$ \\
\hline $2-1$ & 68 & 281 & $4.1^{*}$ & $8.9 \pm 1.9^{* *}$ & $23.2 \pm 3.9^{* *}$ & $67.9 \pm 5.5^{* *}$ \\
\hline $7-1$ & 72 & 274 & $3.8^{*}$ & $8.8 \pm 2.4^{* *}$ & $20.0 \pm 1.6^{* *}$ & $71.2 \pm 3.2^{* *}$ \\
\hline
\end{tabular}

**** Comparisons significantly different to non-transformant (NT) by Dunnett's $t$-tests at the 0.05/0.01 level pre-starved of phosphate for 2 weeks and then provided with phytate for 2 weeks, significantly higher free $\mathrm{P}$ concentrations were detected in leaves of transgenic lines than in NTs $(P<0.05)$ (Fig. 7b).

No significant difference in seedling growth rate was observed between transgenic and NT seedlings. However, transgenic seedlings produced more microtubers than NTs, after phytate was added as an extra $\mathrm{P}$ source into the MS medium for 2 weeks (Fig. 8). The frequency of cultured seedlings forming microtubers was 48 and 3\%, respectively, and that forming microtuber-like organs was both $16 \%$ for line $2-1$ and NT.

The potato-produced phytase improves the bioavailability of phytate $\mathrm{P}$ to weanling pigs

To determine whether the phytase produced in potato tubers may function efficiently in the stomach and improve phytate$\mathrm{P}$ utilization of pigs, feeding tests with growing pigs were performed (Table 3). Our preliminary studies indicated that the potato-produced phytase was more effective than the microbial phytase in improving phytate utilization in animals. Therefore, less potato-produced phytase (50 and $150 \mathrm{U} / \mathrm{kg}$ feed) than the microbial phytase $(500 \mathrm{U} / \mathrm{kg}$ feed $)$ between transgenic lines and NTs (Fig. 7a). For seedlings 

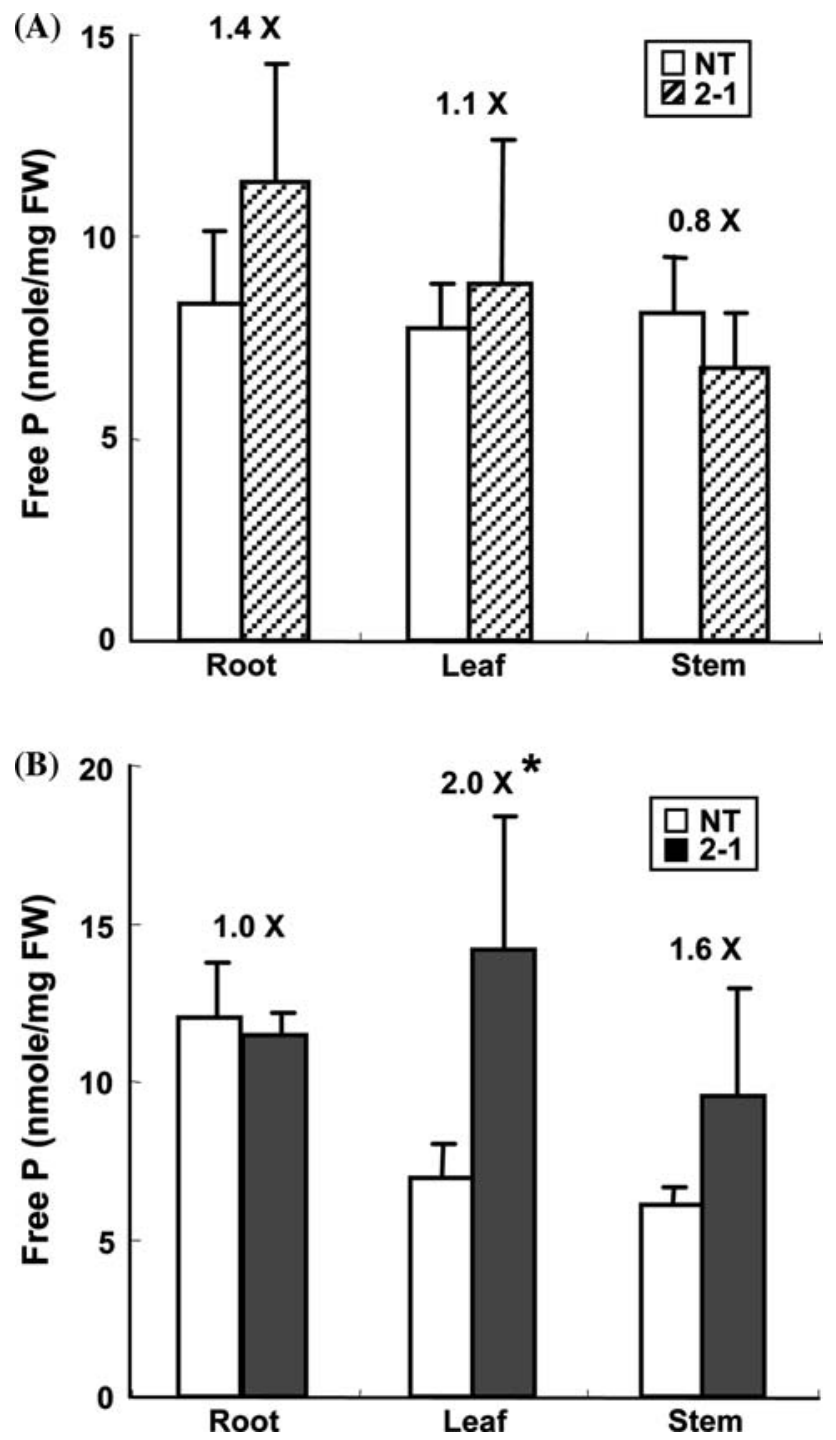

Fig. 7 Overexpression of phytase improves phosphorus acquisition of transgenic potato from phytate. Transgenic potato seedlings (line 2-1) were grown in P-free MS medium for (a) 1 week or (b) 2 weeks, and then transferred to P-free MS medium containing $0.8 \mathrm{mM}$ phytate for 2 weeks. Total Pi contents in roots, leaves and stems of three transgenic potato seedlings were then determined. FW, fresh weight. Error bars indicate the standard deviation of Pi concentrations in different tissues of three plants. * Comparison significantly different to non-transformant (NT) by Dunnett's $t$-test at $P<0.05$

was used in the present study. Pigs fed with low $\mathrm{P}$ diet (without inorganic $\mathrm{P}$ supplement) had less average daily gain than the control group (fed with inorganic $\mathrm{P}$ supplement) $(P<0.05)$, and the supplement of either microbial phytase or potato-produced phytase recovered the daily gain loss caused by low P diet. However, there was no difference in average daily gain between treatments with the microbial and the potato-produced phytase. Feed intake was not altered by the dietary $\mathrm{P}$ content or phytase; however, pigs fed with low $\mathrm{P}$ diet with supplement of the potato-produced phytase at $150 \mathrm{U} / \mathrm{kg}$ had better feed efficiency $(P<0.05)$ than pigs without phytase supplement. Relative to the control group, the serum $\mathrm{P}$ content in pigs fed with low $\mathrm{P}$ diet fell by $14 \%$, while those in pigs supplemented with either microbial or potato-produced phytase maintained at similar levels at the end of the trial $(16$ weeks $)(P<0.05)$. The fecal $P$ content in pigs supplemented with low $\mathrm{P}$ diet, microbial phytase, or potato-produced phytase, fell by $13-16 \%$ as compared to control. Due to the imbalanced $\mathrm{Ca} / \mathrm{P}$ ratio, low $\mathrm{P}$ group had signifidantly $(21 \%)$ lower metacarpal bone strength $(P<0.05)$ as compared to control; however, the mobility of pigs was not affected. The microbial and potato-produced phytase supplements were equally effective $(P<0.05)$ in increasing bone strength, and increasing the level of potatoproduced phytase from 50 to $150 \mathrm{U} / \mathrm{Kg}$ further increased serum $\mathrm{P}$ content and bone strength $(P<0.05)$.

\section{Discussion}

Anabolic regulation of the sporamin promoter is conserved between potato and sweet potato

In the present study, bacterial phytase was produced in transgenic potato tubers at high levels and with high activity under the control of the sweet potato $S P O$ promoter. The high level phytase expression was not associated with copy number of transgene in transgenic potato, indicating that the sweet potato sporamin promoter is highly active in potato. Despite the difference in origins of the potato tuber (a specialized stem) and the sweet potato tuber (a specialized root), these storage organs share many functional and biochemical properties. For example, they both developed as sink organs that accumulate large amounts of reserves, including starch and storage proteins, during the growth of plants. The parallel accumulation of starch and storage proteins, i.e., sporamin and patatin, in sweet potato and potato tubers, respectively (Paiva et al. 1983; Rocha-Sosa et al. 1989; Hattori et al. 1990), and the inducibility of sporamin and patatin promoter activity in stems of sweet potato and potato, respectively, by sucrose (Hattori et al. 1990; Ohta et al. 1991); (Rocha-Sosa et al. 1989; Wenzler et al. 1989) indicate that accumulation of these reserves in tuberous sink tissues are up-regulated by anabolic signals.

In the present study, the $S P O$ promoter conferred highlevel phytase expression in microtubers of cultured transgenic potato (Fig. 2a) and in tubers of soil-grown transgenic potato (Fig. 2b), which suggests that the pathway for transducing anabolic signals to activate sporamin promoter in sink tissues is conserved in potato and sweet potato despite the evolutionary divergence of these two plant species. Phytase activities in leaves and stems from 
Fig. 8 Overexpression of phytase promotes tuber formation when phytate was provided as an additional $\mathrm{P}$ source. Thirty-one stem segments of non-transformant (NT) or transgenic potato line $2-1$, each containing only one bud, were cultured in MS medium containing $0.8 \mathrm{mM}$ phytate for 2 weeks and microtuber formation was examined. Seedlings in boxed areas were enlarged for better visualization of microtubers or microtuber-like organs as indicated by arrows. Frequency indicates numbers of seedlings producing microtubers (highlighted by circles) or microtuber-like organs (highlighted by dashed circles) among 31 seedlings examined

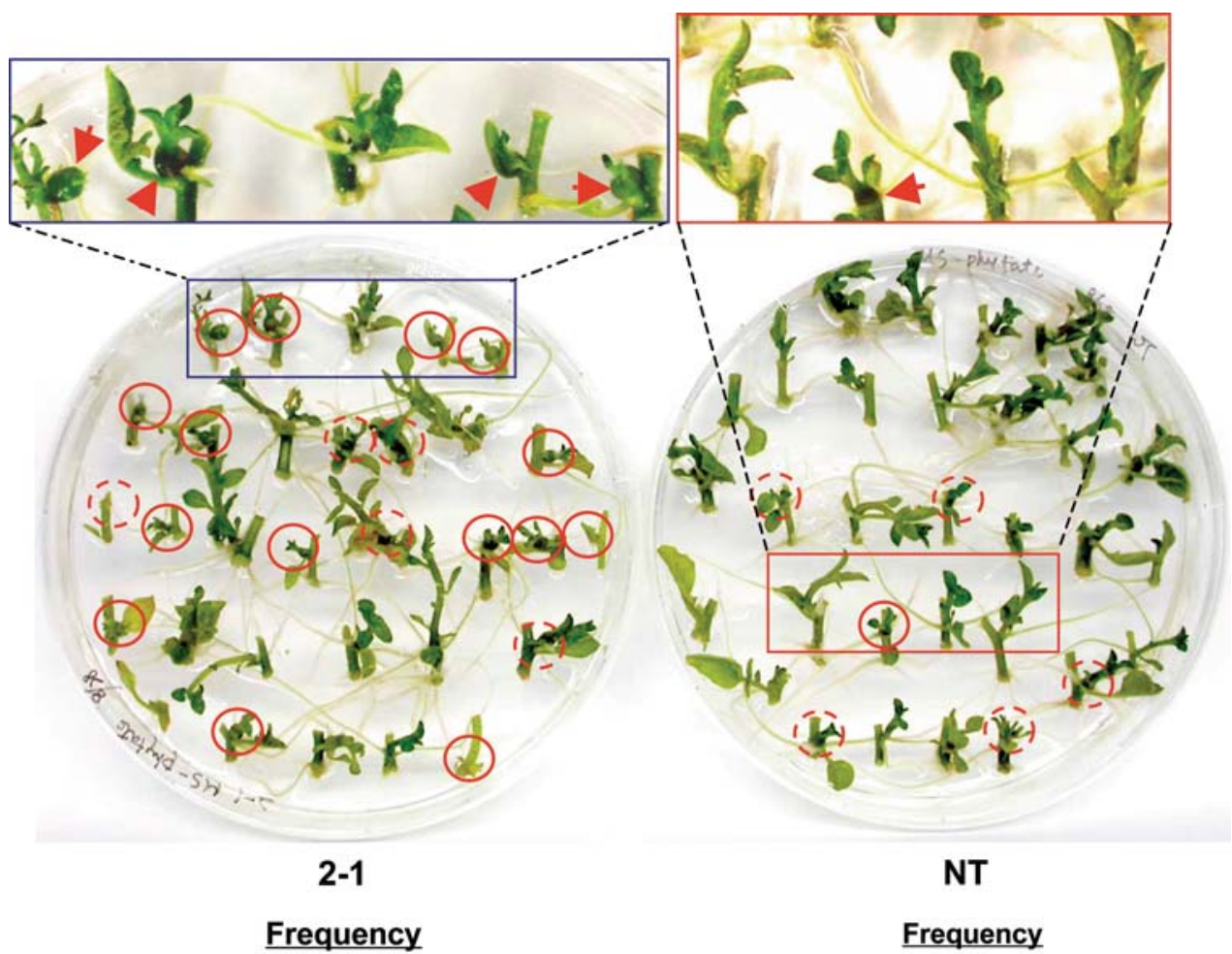

$15 / 31=48 \%$

$5 / 31=16 \%$

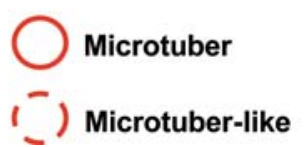

$1 / 31=3 \%$

$5 / 31=16 \%$ tissue-cultured plants were significantly higher than those in leaves and stems from soil-grown plants (Fig. 2). An explanation is that, leaves, stems and microtubers from 3 -week-old tissue-cultured plants might serve as sink tissues as most nutrients were up-taken by roots from the culture medium; consequently, the sporamin promoter was active in directing phytase expression in leaves, stems and microtubers. In contrast, leaves and stems from 3-month-old soil-grown plants served as source tissues as they provided photosynthetic assimilates to tubers; consequently, the sporamin promoter was more active in tubers than in leaves and stems for directing phytase expression.

It is interesting to note that the expression level of phytase was independent of size of transgenic potato tubers (Fig. 4), indicating that the regulation of sporamin promoter activity was coupled with tuber growth by anabolic signals. Additionally, sight variations in phytase activity were observed in tubers originated from the same transformant after three cycles of propagation (Fig. S4) and that could be due to physiological conditions of individual plants.

Overexpression of phytase increases size, number and yield of potato tubers

Several studies have shown that potato tuber size can be manipulated through transgenic approaches. Reductions in potato tuber size is resulted from antisense repression of an ADP-glucose pyrophosphorylase (Muller-Rober et al. 1992) or overexpression of an E. coli inorganic pyrophosphatase (Sonnewald 1992). On the other hand, increase in potato tuber size is obtained by overexpression of an yeast invertase targeted to the apoplast (Sonnewald et al. 1997). In these cases, dramatic changes in carbohydrate contents of transgenic potato tubers are detected. Reduction in potato tuber size could also be obtained by antisense repression of the $\beta$-subunit of an SNF1-related protein kinase complex (StubGAL83), however, in this case, no change in tuber carbohydrate content is detected (Lovas et al. 2003). Ectopic expression of an Arabidopsis PHYB (phytochrome B) gene can increase both tuber number and yield of field-grown transgenic potato, due to increased leaf pigmentation, numbers of chloroplast and enhanced photosynthesis rate (Thiele et al. 1999; Boccalandro et al. 2003). In this transgenic potato, phenotypes of semidwarfism and decreased apical dominance are observed, and delayed senescence is proposed to attribute to increased tuber yield.

In the present study, overexpression of phytase led to increase in tuber size, number and yield of field-grown transgenic potato. Several physiological changes observed in the laboratory and field may account for the increase in tuber growth and yield. First, higher free P concentration 
Table 3 Effect of dietary microbial and potato-produced phytases on growth performance, serum and fecal phosphorus, and metacarpal bone strength of pigs

\begin{tabular}{|c|c|c|c|c|c|}
\hline Items & Control $(+\mathrm{P})$ & Low $\mathrm{P}(-\mathrm{P})$ & $\begin{array}{l}\text { Microbial phytase } \\
(500 \mathrm{U} / \mathrm{kg})\end{array}$ & $\begin{array}{l}\text { Potato-produced } \\
\text { phytase }(50 \mathrm{U} / \mathrm{kg})\end{array}$ & $\begin{array}{l}\text { Potato-produced } \\
\text { phytase }(150 \mathrm{U} / \mathrm{kg})\end{array}$ \\
\hline Initial body weight $(\mathrm{kg})$ & $32.7 \pm 0.1(100)$ & $33.0 \pm 0.2(101)$ & $32.5 \pm 0.1(99)$ & $33.0 \pm 1.1(101)$ & $32.5 \pm 0.2(99)$ \\
\hline Final body weight (kg) & $118.0 \pm 2.1(100)$ & $113.3 \pm 2.5(96)$ & $118.9 \pm 2.1(101)$ & $116.3 \pm 2.1(99)$ & $118.6 \pm 3.6(101)$ \\
\hline Average daily gain (kg) & $0.76 \pm 0.02(100)$ & $0.72 \pm 0.02^{\mathrm{a}}(95)$ & $0.77 \pm 0.02^{\mathrm{b}}(101)$ & $0.74 \pm 0.01(97)$ & $0.77 \pm 0.03$ \\
\hline Average daily feed intake $(\mathrm{kg})$ & $2.16 \pm 0.09(100)$ & $2.11 \pm 0.01(98)$ & $2.22 \pm 0.11(103)$ & $2.13 \pm 0.11(99)$ & $2.13 \pm 0.12(99)$ \\
\hline Feed efficiency (Feed/gain) & $2.83 \pm 0.05(100)$ & $2.93 \pm 0.10^{\mathrm{a}}(104)$ & $2.88 \pm 0.07(102)$ & $2.86 \pm 0.11(101)$ & $2.77 \pm 0.04^{\mathrm{b}}(98)$ \\
\hline \multicolumn{6}{|l|}{ Serum phosphorus (mg/dl) } \\
\hline $0 \mathrm{wk}$ & $10.8 \pm 0.9(100)$ & $10.2 \pm 1.1(94)$ & $10.3 \pm 1.6(95)$ & $10.7 \pm 1.2(99)$ & $10.6 \pm 1.4(98)$ \\
\hline $16 \mathrm{wk}$ & $8.0 \pm 0.3^{\mathrm{a}}(100)$ & $6.9 \pm 0.4^{\mathrm{b}}(86)$ & $7.8 \pm 0.7^{\mathrm{a}}(98)$ & $7.6 \pm 0.9(95)$ & $7.9 \pm 1.0^{\mathrm{a}}(99)$ \\
\hline \multicolumn{6}{|l|}{ Fecal phosphorus (\%) } \\
\hline $0 \mathrm{wk}$ & $2.43 \pm 0.13(100)$ & $2.48 \pm 0.15$ & $2.60 \pm 0.16(107)$ & $2.43 \pm 0.11(100)$ & $2.49 \pm 0.17(102)$ \\
\hline $16 \mathrm{wk}$ & $2.21 \pm 0.08$ & $1.92 \pm 0.36(87)$ & $1.85 \pm 0.01(84)$ & $1.85 \pm 0.09(84)$ & $1.90 \pm 0.15(86)$ \\
\hline \multicolumn{6}{|l|}{ Metacarpal bone strength (kg) } \\
\hline $16 \mathrm{wk}$ & $182 \pm 20^{\mathrm{a}}(100)$ & $143 \pm 14^{\mathrm{bx}}(79)$ & $195 \pm 22^{y}(107)$ & $162 \pm 10^{\mathrm{c}}(89)$ & $172 \pm 9^{\mathrm{y}}(95)$ \\
\hline
\end{tabular}

a, b, c; $x, y$ Means within the same row with different superscript differ significantly from each other $(P<0.05)$. Values in parentheses indicate $\%$ of the wild type

was detected in leaves of transgenic seedlings than NTs after pre-phosphate starvation and subsequent application of phytate in culture medium as the sole P source (Fig. 7), indicating overexpression of phytase enhanced $\mathrm{P}$ utilization from phytate by transgenic potato. Under P-deficient conditions, tomato roots could be induced to secrete phytase to hydrolyze organic $\mathrm{P}$ in soil, such as phytate and nucleic acid, to liberate inorganic $\mathrm{P}$ available to plants ( $\mathrm{Li}$ and Tadano 1996). However, the quantity of phytase secreted by plants is normally limited even under the induced condition ( $\mathrm{Li}$ et al. 1997a). Targeted overexpression of fungus or plant derived phytase with signal peptide in roots of various transgenic plants species has significantly enhanced phytase secretion into rhizosphere and $\mathrm{P}$ uptake efficiency when phytate was supplied as the sole P source (Richardson et al. 2001; Zimmermann et al. 2003; George et al. 2005; Xiao et al. 2005). In the present study, since phytase was expressed with the sporamin signal peptide, very likely the recombinant phytase was also secreted from roots of transgenic potato and enhanced $\mathrm{P}$ utilization from phytate present in the organic fertilizer.

Second, higher levels of chlorophylls a and $\mathrm{b}$ and carotenoids were detected in leaves of field-grown plants (Fig. 6), indicating overexpression of phytase could enhanced photosynthesis rate of transgenic potato. In higher plants, these three groups of pigments constitute the major components of the antenna complex for light absorption and energy transfer in the reaction center of the photosynthesis apparatus in chloroplast (Taiz and Zeiger 2006). P is an integral component of important compounds of plant cells, including the sugar-phosphate intermediates of respiration and photosynthesis, phospholipids in plant membranes, and nucleotides used in plant energy metabolism (e.g., ATP) and in DNA and RNA (Taiz and Zeiger 2006). Increase in abundance of these pigments, indicating increase in chloroplast numbers, could have increased the photosynthesis rate of transgenic potato, and consequently more carbon assimilates (sugars) flow from mature leaves into the sink tissues, e.g. growing leaves and tubers. Tuber formation in potato has been shown to be associated with an increase in the photosynthetic rate in leaves (Lorenzen and Ewing 1990). In transgenic potato overexpressing an Arabidopsis phytochrome $\mathrm{B}$, increase in leaf pigmentation has also been shown to correlate with increased photosynthesis rate and tuber yield (Thiele et al. 1999). A 3- to 4-fold increase in dry weight and 4- to 5.5-fold increase in $\mathrm{P}$ concentration is observed in transgenic Arabidopsis roots overexpressing a secretory legume phytase, although change in leaf pigment or chloroplast content is not mentioned (Xiao et al. 2005). It appears that there is a correlation among $\mathrm{P}$ concentration, photosynthetic rate and tuber yield in potato, which may explain up to $22 \%$ increase in tuber yield of transgenic potato was obtained in the present study (Table 1).

Third, as compared with NTs, an earlier microtuber formation was observed in transgenic potato seedlings than NTs cultured in MS medium (containing $1.25 \mathrm{mM}$ $\mathrm{KH}_{2} \mathrm{PO}_{4}$ ) with $0.8 \mathrm{mM}$ phytate as an additional $\mathrm{P}$ source (Fig. 8), indicating enhanced $\mathrm{P}$ acquisition facilitated microtuber formation. In our field trials, meat moss containing chicken excrement also provided phytate as an additional $\mathrm{P}$ source. As a consequence of improved $\mathrm{P}$ utilization from phytate, increased number, larger size, and higher yield of tubers than NTs were obtained in transgenic potato overexpressing phytase. 
$\mathrm{P}$ deficiency in soil is a major constraint for agricultural production worldwide; however, world resources of rock phosphate are estimated to be depleted by 2050 (Vance et al. 2003). Improvement of plant $P$ uptake from phytate will not only reduce the input and negative environmental impacts of chemical fertilizers but also could remove excessive organic $\mathrm{P}$ from certain land areas with extensive poultry industry. The approach of overexpressing secretory phytase could be applied to other crops to improve plant nutrient, growth and phytoremediation, and will thus have significant impacts on sustainable agriculture.

The potato-produced phytase with broad $\mathrm{pH}$ optima is an ideal feed additive

Phytase stable and active in an acidic environment is essential for the hydrolysis of phytate in animal gastrointestinal tracks. In the present study, the optimal $\mathrm{pH}$ for phytase activity in transgenic potato tubers shifted from an original single peak of 4.5 (Golovan et al. 2000) to a bi-hump peak of 2.5 and 5.5 (Fig. 5a), similar to that seen in germinated transgenic rice seeds (Hong et al. 2004). The phytase in transgenic potato tubers had high activities over the $\mathrm{pH}$ range 1.5-6.0. One possible explanation for the high activity at broader $\mathrm{pH}$ ranges could be due to structural changes of the bacterial phytase expressed in plants. The fungal phyA phytase expressed in alfalfa has a shifted $\mathrm{pH}$ optima for maximal enzyme activity compared with the native phytase, where a difference in enzyme glycosylation has been proposed for the altered $\mathrm{pH}$ optima (Ullah et al. 2002). Three potential glycosylation sites were present in appA phytase, but whether the enzyme is glycosylated in transgenic potato tubers is not known. The broad and acidic optimal $\mathrm{pH}$ profiles of the phytase expressed in potato tubers would allow the enzyme to function well in both the stomach and small intestine of animals, and are essential features for any potential use as feed additives. The temperature optima profiles $\left(50-60^{\circ} \mathrm{C}\right)$ of phytase expressed in potato tubers were similar to the native form phytase (Golovan et al. 2000), indicating that the shift of $\mathrm{pH}$ optima is independent of the thermotolerance of the enzyme.

Our studies indicate that the potato-produced phytase is just as effective as the commercially available microbial phytase in increasing the bioavailability of phytate-P to weanling pigs. Previous studies have indicated that an increase in $\mathrm{Ca} / \mathrm{P}$ ratio could inhibit pig growth, particularly in terms of average daily gain and feed efficiency (Cera and Mahan 1988; Bertram et al. 1994; Liu et al. 1998). However, in the present study, supplementing either microbial or potato-produced phytase to pigs fed the low $\mathrm{P}$ diet, with $\mathrm{Ca} / \mathrm{P}$ ratios of 1.53 and 1.69 compared with the control group diet with a $\mathrm{Ca} / \mathrm{P}$ ratio of 1.27 , both average daily gain and feed efficiency were improved.
Additionally, in comparison with the low $\mathrm{P}$ diet, phytase supplement improved dietary $\mathrm{P}$ utilization, resulting in higher serum $P$ and better bone strength (Table 3 ). Therefore, results of our animal feeding studies indicated that the supplementation of microbial and potato-produced phytase to pigs fed low $\mathrm{P}$ diet improves dietary $\mathrm{P}$ utilization and growth performance. The lower requirement of potato-produced phytase compared to microbial phytase for diet supplementation could be due to higher specific activity, broader low $\mathrm{pH}$ optima, and higher protease resistance (Cheng et al. 1999; Golovan et al. 2000), and likely protection by potato tuber tissues in the animal digestive system.

In summary, our studies have demonstrated several unique features: (1) high activity of the sweet potato sporamin promoter in potato making this promoter an ideal alternative choice for expressing recombinant proteins in transgenic potato tubers; (2) high-level expression of phytase with high activity over broad $\mathrm{pH}$ ranges making potato tubers a suitable phytase carrier; (3) promising results of animal feeding tests indicating that transgenic potato tubers containing recombinant phytase are an efficient feed additive; (4) expression of secretory phytase in transgenic potato improving $\mathrm{P}$ utilization and increasing size, number and yield of potato tubers when organic fertilizers containing phytate as a sole $\mathrm{P}$ source.

Acknowledgement We thank Drs. Tuan-hua David Ho and Harry I. Wilson for their critical reviews of this manuscript, Drs. Chang-Sheng Wang, Tzyy-Jen Chiou and Chin-Wen Ho, and Ms. Shu-I Lin and Lin-ChihYu for technical assistance. This work was supported by grants from Academia Sinica, the National Science Council (NSC872611-B-001-004-B30, NSC88-2311-B-001-028-B30, NSC89-2311B001-050-B29) of the Republic of China.

\section{References}

AOAC (1984) Official methods of analysis, 14th edn. Association of Official Analytical Chemists, Arlington, VA

Artsaenko O, Kettig B, Fiedler U, Conrad U, During K (1998) Potato tubers as a biofactory for recombinant antibodies. Mol Breed $4: 313-319$

Bertram MJ, Stahly TS, Ewan RC (1994) Impact of available dietary phosphorus regimen on growth of pigs with a moderate and low genetic capacity for lean tissue growth. ISU Swine Res. Report, pp 26-29, USA

Boccalandro HE, Ploschuk EL, Yanovsky MJ, Sanchez RA, Gatz C, Casal JJ (2003) Increased phytochrome B alleviates density effects on tuber yield of field potato crops. Plant Physiol 133:1539-1546

Cera KR, Mahan DC (1988) Effect of dietary calcium and phosphorus level sequences on performance, structural soundness and bone characteristics of growing-finishing swine. J Anim Sci 66:1598-1605

Cheng KJ, Sellnger LB, Yanke LJ, Bae HD, Zhou L, Forsberg CW (1999) Phytases of ruminal microorganisms. US patent No. $5,939,303$

Chiou TJ, Aung K, Lin SI, Wu CC, Chiang SF, Su CL (2006) Regulation of phosphate homeostasis by MicroRNA in Arabidopsis. Plant Cell 18:412-421 
Chong DK, Langridge WH (2000) Expression of full-length bioactive antimicrobial human lactoferrin in potato plants. Transgenic Res 9:71-78

Dalal RC (1977) Soil organic phosphorus. Adv Agron 29:83-117

Denbow DM, Grabau EA, Lacy GH, Kornegay ET, Russell DR, Umbeck PF (1998) Soybeans transformed with a fungal phytase gene improve phosphorus availability for broilers. Poult Sci $77: 878-881$

De Wilde C (2002) Expression of antibodies and Fab fragments in transgenic potato plants: a case study for bulk produciton in crop plants. Mol Breed 9:271-282

Farran I, Sanchez-Serrano JJ, Medina JF, Prieto J, Mingo-Castel AM (2002) Targeted expression of human serum albumin to potato tubers. Transgenic Res 11:337-346

George TS, Simpson RJ, Hadobas PA, Richardson AE (2005) Expression of a fungal phytase gene in Nicotiana tabacum improves phosphorus nutrition of plants grown in amended soils. Plant Biotechnol J 3:129-140

Golovan S, Wang G, Zhang J, Forsberg CW (2000) Characterization and overproduction of the Escherichia coli appA encoded bifunctional enzyme that exhibits both phytase and acid phosphatase activities. Can J Microbiol 46:59-71

Hattori T, Nakamura K (1988) Genes coding for the major tuberous root protein of sweet potato: Identification of putative regulatory sequence in the $5^{\prime}$ upstream region. Plant Mol Biol 11:417-426

Hattori T, Nakagawa S, Nakamura K (1990) High-level expression of tuberous root storage protein genes of sweet potato in stems of plantlets grown in vitro on sucrose medium. Plant Mol Biol 14:595-604

Holford I (1997) Soil phosphorus: its measurement, and its uptake by plants. Aust J Soil Res 35:227-239

Hong C-Y, Cheng K-J, Tseng T-H, Wang C-S, Liu L-F, Yu S-M (2004) Production of two highly active bacterial phytases with broad $\mathrm{pH}$ optima in germinated transgenic rice seeds. Transgenic Res 13:29-39

Li MG, Tadano T (1996) Comparison of characteristics of acid phosphatases secreted from roots of lupin and tomato. Soil Sci Plant Nutr 42:753-763

Li MG, Osaki M, Rao RM, Tadano T (1997a) Secretion of phytase from roots of several plant species under phosphorus-deficient conditions. Plant Soil 195:161-169

Li J, Hegeman CE, Hanlon RW, Lacy GH, Denbow MD, Grabau EA (1997b) Secretion of active recombinant phytase from soybean cell-suspension cultures. Plant Physiol 114:1103-1111

Lichtenthaler H (1987) Chlorophylls and carotenoids: pigments of photosynthetic biomembranes. In: Packer L, Douce R (eds) Plant cell membrane in methods in enzymology, vol 148. Academic Press, pp 350-382

Liu J, Bollinger DW, Ledoux DR, Veum TL (1998) Lowering the dietary calcium to total phosphorus ratio increases phosphorus utilization in low-phosphorus corn-soybean meal diets supplemented with microbial phytase for growing-finishing pigs. J Anim Sci 76:808-813

Lorenzen JH, Ewing EE (1990) Changes in tuberization and assimilate partitioning in potato (Solanum tuberosum) during the first 18 days of photoperiod treatment. Ann Bot 66:457-464

Lovas A, Bimbo A, Szabo L, Banfalvi Z (2003) Antisense repression of StubGAL83 affects root and tuber development in potato. Plant J 33:139-147

Maenz DD (2001) Enzymatic characterisation of phytases as they relate to their use in animal feeds. In: Bedford MR, Partridge GG (eds) Enzymes in farm animal nutrition. CABI Publishing, pp 61-84

Mudge SR, Smith FW, Richardson AE (2003) Root-specific and phosphate-regulated expression of phytase under the control of a phosphate transporter promoter enables Arabidopsis to grown on phytase as a sole P source. Plant Sci 165:871-878

Muller-Rober B, Sonnewald U, Willmitzer L (1992) Inhibition of the ADP-glucose pyrophosphorylase in transgenic potatoes leads to sugar-storing tubers and influences tuber formation and expression of tuber storage protein genes. Embo J 11:1229-1238

Ohta S, Hattori T, Morikami A, Nakamura K (1991) High-level expression of a sweet potato sporamin gene promoter: betaglucuronidase (GUS) fusion gene in the stems of transgenic tobacco plants is conferred by multiple cell type-specific regulatory elements. Mol Gen Genet 225:369-378

Paiva E, Lister R, Park WD (1983) Induction and accumulation of major tuber proteins of potato in stems and petioles. Plant Physiol 71:161-168

Pen J, Verwoerd TC, van Paridin PA, Beukeder RF, van der Elzen PJM, Geerse K, van der Klis JD, Versteegh HA, van Ooyen AJ, Hoekema A (1993) Phytase-containing transgenic seed as a novel feed additive for improved phosphorus utilization. Bio/ Technology 11:811-814

Richardson AE, Hadobas PA, Hayes JE (2001) Extracellular secretion of Aspergillus phytase from Arabidopsis roots enables plants to obtain phosphorus from phytate. Plant J 25:641-649

Richter LJ, Thanavala Y, Arntzen CJ, Mason HS (2000) Production of hepatitis B surface antigen in transgenic plants for oral immunization. Nat Biotechnol 18:1167-1171

Rocha-Sosa M, Sonnewald U, Frommer W, Stratmann M, Schell J, Willmitzer L (1989) Both developmental and metabolic signals activate the promoter of a class I patatin gene. Embo J 8:23-29

SAS (1989) SAS/STAT User's Guide (Release 6.12) SAS Inst. Inc., Cary, NC

Scheller J, Guhrs KH, Grosse F, Conrad U (2001) Production of spider silk proteins in tobacco and potato. Nat Biotechnol 19:573-577

Sheerman S, Bevan M (1988) A rapid transformation method for Solanum tuberosum using binary Agrobacterium tumefaciens vectors. Plant Cell Rep 7:13-16

Sheu JJ, Yu TS, Tong WF, Yu SM (1996) Carbohydrate starvation stimulates differential expression of rice alpha-amylase genes that is modulated through complicated transcriptional and posttranscriptional processes. J Biol Chem 271:26998-27004

Shimizu M (1992) Purification and characterizaiton of phytase from Bacillus subtilis (natto) N-77. Biosci Biotech Biochem 56: 1266-1269

Sonnewald U (1992) Expression of E. coli inorganic pyrophosphatase in transgenic plants alters photoassimilate partitioning. Plant $\mathbf{J}$ 2:571-581

Sonnewald U, Hajirezaei MR, Kossmann J, Heyer A, Trethewey RN, Willmitzer L (1997) Increased potato tuber size resulting from apoplastic expression of a yeast invertase. Nat Biotechnol 15:794-797

Tacket CO, Mason HS, Losonsky G, Estes MK, Levine MM, Arntzen CJ (2000) Human immune responses to a novel norwalk virus vaccine delivered in transgenic potatoes. J Infect Dis 182: 302-305

Taiz L, Zeiger E (2006) Abscisic acid: a seed maturation and antistress signal. Chapter 23, In: Plant physiology, 4th edn. Sinauer Associates, Inc., pp 594-613

Thiele A, Herold M, Lenk I, Quail PH, Gatz C (1999) Heterologous expression of Arabidopsis phytochrome B in transgenic potato influences photosynthetic performance and tuber development. Plant Physiol 120:73-82

Ullah AH, Sethumadhavan K, Mullaney EJ, Ziegelhoffer T, AustinPhillips S (2002) Cloned and expressed fungal phyA gene in alfalfa produces a stable phytase. Biochem Biophys Res Commun 290:1343-1348 
Vance CP, Uhde SC, Allan DL (2003) Phosphorus acquistion and use: critical adaptations by plants for securing a nonrenewable resource. New Phytol 157:423-447

Visser RG, Stolte A, Jacobsen E (1991) Expression of a chimaeric granule-bound starch synthase-GUS gene in transgenic potato plants. Plant Mol Biol 17:691-699

Wang P, Hu C (1982) In vitro mass tuberization and virus-free seedpotato production in Taiwan. Am Potato J 59:33-37

Wenzler HC, Mignery GA, Fisher LM, Park WD (1989) Analysis of a chimeric class-I patatin-GUS gene in transgenic potato plants: High level expression in tubers and sucrose-inducible expression in cultured leaf and stem explant. Plant Mol Biol 12:41-50
Xiao K, Harrison MJ, Wang ZY (2005) Transgenic expression of a novel M. truncatula phytase gene results in improved acquisition of organic phosphorus by Arabidopsis. Planta 222:27-36

Yu S-M (2003a) Sweet potato sporamin gene promoter. US Patent Application No. 20030177517: Publication date: 01/18/2003

Yu S-M (2003b) Sweet potato sporamin gene promoter. European Patent Application No. EP1348763: Publication date: 10/01/ 2003

Zimmermann P, Zardi G, Lehmann M, Zeder C, Amrhein N, Frossard E, Bucher M (2003) Engineering the root-soil interface via targeted expression of a synthetic phytase gene in trichoblasts. Plant Biotechnol J 1:353-360 